\title{
California Micro Devices Corp.: A Class Discussion Of Auditor's Ethical, Legal, And Professional Responsibilities
}

Freddie Choo, (Email: fchoo@sfsu.edu),California State University, San Franciso Kim Tan ,(Email: kbtan@toto.csustan.edu), California State University, San Francisco Robin Wagner, (Email: rwagner@sfsu.edu), San Francisco State University

\begin{abstract}
This short case is best for an open discussion in an upper-division auditing class. The class discussion questions intensify students' learning experience on (1) auditor's ethical responsibility to resolve tough ethical issues, (2) auditor's legal responsibility to detect fraudulent financial reporting, and (3) auditor's professional responsibility to conform to auditing standards. Additional class discussion questions, optional hands-on internet experience, and class discussion guide are provided. The case illustrates how a high-technology company succumbed to the pressure of unrealistic financial goals in an industry that is characterized by rapid technology change, intense competitive pressure, and volatile demand patterns for computer chips. High-level management at the company orchestrated fraudulent financial reporting schemes by creating fictitious sales and shipping bogus inventories. The fraud was uncovered only after the company's Board of Directors appointed a third auditor to investigate the sophisticated fraudulent schemes. However, the action came a little too late as the shareholders began to file class-action securities lawsuits against the company and its former auditor.
\end{abstract}

\section{INTRODUCTION}

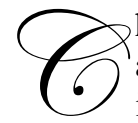
handrashkar M. Desaigoudar founded California Micro Devices in 1980, a company that specializes in assembling electronic components and selling computer chips in the Silicon Valley of California. Its independent auditor, Price Waterhouse, first noted California Micro Devices' questionable business and accounting practices in 1989. In that year's audit, Price Waterhouse (now PriceWaterhouseCoopers) asked California Micro Devices to restate its financial statements to show a fourth-quarter loss of $\$ 3$ million instead of a $\$ 1$ million loss. Shortly after the 1989 audit report was issued, California Micro Devices switched its auditor to Coopers and Lybrand (now PriceWaterhouseCoopers). In 1994, Coopers and Lybrand abruptly resigned as auditors for California Micro Devices. Subsequently, California Micro Devices hired a third "Big Six" accounting firm, Ernst and Young, to perform a special audit to determine whether the company engaged in financial irregularities. Ernst and Young reported, "We found widespread accounting and other irregularities." ${ }^{1}$ As a result, of Ernst and Young's special audit, California Micro Devices announced that it would restate its profit for the fiscal year of 1994 from a $\$ 5.1$ million profit to a loss of $\$ 15.2$ million. At about the same time, the Securities and Exchange Commission's (SEC) San Francisco office began an investigation into California Micro Devices' business and accounting practices for possible violations of federal securities laws and for illegal insider trading. In 1995, the National Association of Securities Dealers (NASD) abruptly delisted California Micro Devices after it discovered that the company failed to file its financial statements with the SEC in a timely manner. Moreover, Ron Romito, a former chief accounting officer, pleaded guilty to one count of insider trading. All the bad news resulted in shareholders filing class-action securities lawsuits against the company in the United States District Court for the Northern District of California. Other defendants named in the class actions include the company's former auditor Coopers and Lybrand.

\footnotetext{
${ }^{1}$ Quotes from CMD's 1994 10-k statements in the SEC's EDGAR website.
} 


\section{RED FLAGS ON CALIFORNIA MICRO DEVICES}

Two former executives raised red flags about the company's questionable business and accounting practices. In 1994, Satish Kumar, a former executive who left California Micro Devices after trying to blow the whistle on company Chairman Desaigoudar, said the company inflated its sales by creating phony sales transactions. Another former executive said that he was present at two company meetings in 1990 when Desaigoudar instructed another executive "to extend the quarter" in order to improve sales figures. According to these two ex-executives, Desaigoudar's instructions to "extend the quarter" or "keep the quarter open" were clear signals to find creative ways to inflate sales in the quarter. Given these signals, the company would ship products after the quarter ended, but book them as sales in the previous quarter.

The company also would ask customers to accept additional products sooner than needed and then allow these customers to put off payment for up to six months. If the customers refused to accept the products, the company would prepare sales invoices as if they were being shipped. The company would create phony packing slips and send the invoices to the customers. The products would be locked in an empty office, placed in an employee's garage, or sent to a distributor or sales representative until the customers requested the remaining portions.

Kumar, the former executive, cited an incident in 1989 when Motorola Malaysia ordered a large quantity of chips to be delivered over a period of time. He said that California Micro Devices asked Motorola Malaysia to accelerate its delivery schedule, but Motorola Malaysia refused to do so. Kumar revealed that the undelivered chips were put in a closet at the company's headquarters and then shipped to a sales representative. The sales representative kept them until Motorola Malaysia actually scheduled for their delivery. Another incident disclosed by a former sales representative corroborated Kumar's statements. The former sales representative said that, in December 1992, he received 50,000 chips (worth about \$50,000) that had been produced at the company's Tempe, Arizona plant. He kept them in the closet of his home until he was told to release them. "The reason was to show shipments prior to the end of the quarter. It was a normal (company) policy. If they could ship ahead of schedule, they would do it," the former sales representative said. $^{2}$

In June 1994, a number of financial analysts also raised red flags about California Micro Devices' questionable business and accounting practices. The financial analysts noted steadily increasing accounts receivable that stretched out longer than one quarter, suggesting that California Micro Devices was aggressively shipping chips to window-dress its sales and earnings. The company blamed the high accounts receivable on favorable credit terms extended to ten Asian distributors "to avoid shipment delays." However, avoiding shipment delays by relaxing customers' credit terms is a questionable business practice. This practice backfired on California Micro Devices when, in August 1994, the company announced that it was taking back $\$ 8.3$ million in unsold chips. Desaigoudar said that these unsold chips were coming from the Asian distributors who were unable to pay for the products. However, in a conference call with analysts, Desaigoudar startled the audiences by acknowledging the company had known all along that these distributors' credit terms were questionable when the orders were shipped. When asked who the ten Asian distributors were and where they were located, Desaigoudar would not give a specific answer.

\section{AUDITORS OF CALIFORNIA MICRO DEVICES}

In 1989, its independent auditor, Price Waterhouse (now PriceWaterhouseCoopers), first noted California Micro Devices' questionable business and accounting practices. In the 1989-year interim audit of California Micro Devices' interim financial statements, Price Waterhouse advised California Micro Devices that it had "material" internal control weaknesses. In filing its review report of the company's interim financial statements with the Securities and Exchange Commission, Price Waterhouse also noted "several inadequacies in the procedures and practices used by the company to compile and report interim financial information." 3

\footnotetext{
${ }^{2}$ Quotes from the financial press of the San Francisco Chronicle, October 17, 1994.

${ }^{3}$ Quotes from CMD's 1989 10-Q statements in COMPACT disclosure disk.
} 
In the 1989-year final audit, Price Waterhouse asked California Micro Devices to restate its year-end financial statements to show a fourth-quarter loss of \$3 million instead of a \$1 million loss that had been disclosed in an earlier press release. The restatement was necessary after Price Waterhouse noticed "revenue and expense cut-off errors" at the end of several quarters. Given these errors, Price Waterhouse was concerned about the professional competence of several California Micro Devices' financial personnel. It recommended that California Micro Devices "upgrade the depth and experience" of its financial personnel "in order to meet increased financial reporting demands," and specifically recommended that it hire a new controller, chief accounting officer and chief financial officer. The company eventually hired a new chief executive officer, Jeff Kalb, and a new chief accounting officer who replaced Steve Henke, the long time chief financial officer. Steve Henke was demoted to treasurer on the advice of Price Waterhouse in 1989. However, he remained the company's principal financial contact and often sat alongside Desaigoudar in meetings with the financial community.

Shortly after the 1989 audit report was issued, California Micro Devices decided not to retain Price Waterhouse for its future audits. In its 8-K filing with the SEC, California Micro Devices cited disagreement over Price Waterhouse's audit fee as the main reason for terminating the auditor. Another "Big Six" accounting firm, Coopers and Lybrand, succeeded Price Waterhouse as the company's independent auditor in 1990. In 1994, Coopers and Lybrand abruptly resigned as auditors for California Micro Devices. Subsequently, a special committee of directors hired a third "Big Six" accounting firm, Ernst and Young, to perform a special audit to determine whether the company engaged in financial irregularities.

In October 1994, Ernst and Young reported that, "We found widespread accounting and other irregularities ... This wasn't just the case of a company making one or two miscalculations ... There was a deliberate effort to overstate California Micro Devices' performance." ${ }^{4}$ Some of Ernst and Young's findings were:

- Revenue recognition problem - California Micro Devices reported sales in one quarter that had occurred in another, subsequent, quarter.

- Revenue recognition problem - California Micro Devices reported sales as soon as products were put out on consignment.

- Fraudulent sales practice - California Micro Devices created false sales invoices and bills of lading.

- Misclassification of accounts - California Micro Devices inflated gross profit intentionally by misclassifying nonproduct sales as product sales.

California Micro Devices announced in February 1995 that it would restate its profit for the fiscal 1994 year, which ended on June 30, to a loss of $\$ 15.2$ million from a $\$ 5.1$ million profit. The company also would restate its sales revenues in the 1994 fiscal year to $\$ 22.3$ million from $\$ 38$ million. Since the company's former auditor, Cooper and Lybrand, resigned and withdrew its audit report associated with the financial statements for the fiscal year ended June 30, 1994, the restated financial statements for the 1994 fiscal year were unaudited.

\section{CLASS DISCUSSION QUESTIONS}

We teach auditor's professional, ethical, and legal environments in our upper-division auditing class very early in the semester. After we have covered the educational points in this area, this short case is handed out to the students for an open discussion in class. The case does not depend, for its resolution, on anything esoteric or technical and therefore the students enjoy reading and discussing the case. Although we have not added fictional dialogue, parties and drama, the case seem to intensify the students' learning experience reasonably well.

\section{Auditor's Ethical Responsibilities}

In 1995, the independent auditor has damaging information about the company chairperson's tax liabilities relating to executive perks and his insider-trading activities. What are the auditor's ethical responsibilities if

\footnotetext{
${ }^{4}$ Quotes from CMD's 1994 10-K statements in the SEC's EDGAR website.
} 
(a) The Internal Revenue Service (IRS) approaches the auditor to be an informant in its investigation of the chairperson's tax liabilities relating to executive perks? And if

(b) The Securities and Exchange Commission (SEC) approaches the auditor to be a whistle-blower relating to the chairperson's insider-trading activities? In addition, consider the implications of the Sarbanes-Oxley Act of 2002 on whistle blowing.

\section{Auditor's Legal Responsibilities}

In 1994, a class action lawsuit by the company's shareholders names its auditor as a defendant. The allegations against the auditor in the class actions are that it violated Section 10(b) and Rule 10b-5 of the Securities Exchange Act of 1934 by disseminating false and misleading financial statements and reports for the fiscal year ended June 30, 1993 and June 30, 1994.

(a) When the company's shareholders file a lawsuit against the auditor under Section 10(b) and Rule 10b-5 of the 1934 Act, what general elements of proof must they (the plaintiffs) establish to make a prima facie case? What is the auditor's best defense under the statutory law?

(b) The company's shareholders also file tort actions against the auditor for professional negligence under the common law. What general elements of proof must they (the plaintiffs) establish to make a prima facie case? What is the auditor's best defense under the common law?

\section{Auditor's Professional Responsibilities}

Communication between predecessor and successor auditors is critical when a change of auditors takes place.

(a) What audit communication procedures should a successor auditor perform when a predecessor auditor leaves amid concerns of improper revenue cut-off procedures and incompetent financial personnel at a client company?

(b) What audit communication procedures should a successor auditor perform when a predecessor auditor withdraws its audit report associated with prior-year financial statements that the successor auditor believes should be revised?

\section{ADDITIONAL CLASS DISCUSSION QUESTIONS}

We realized that not all instructors would necessarily discuss the above three topic areas in the same class period. For example, some instructors might discuss them in conjunction with additional topic areas as they come to light throughout a semester/quarter. Thus, we provided some additional topic areas and potential issues for class discussion below. The instructors could determine which topic areas to discuss within the context of California Micro Devices.

\section{Audit Client Acceptance/Retention}

Issues that could be raised include whether an auditor has an obligation (ethical, legal or professional) to provide audit services to a client. For example, why would one auditor take on a client that another auditor has fired? How can the client acceptance/retention decision be used to mitigate an auditor's business risk? Would the process of client acceptance decisions differ from the process used for client retention decisions?

\section{Fraud Detection}

The basic case information provides a great opportunity to bring up issues dealing with fraudulent financial reporting and the auditor's role. Discussion questions could relate to identification of fraud risk factors, auditors' responsibility for fraud detection, and what is the difference between earnings management and fraudulent financial reporting? 


\section{Audit Testing Procedures}

The basic case information can be used to discuss an auditor's tests of controls/tests of balances procedures. For example, what procedures would an auditor typically perform to determine whether recognized revenue is valid? What would be the best audit procedure for testing fraudulent sales practice? How does an auditor identify misclassification of accounts?

\section{Audit Reports}

The basic case information could lead to interesting discussion questions about an auditor's reporting options when material misstatements are discovered. For example, how does an auditor decide among the reporting options to issue a qualified, adverse or disclaimer opinion? Would an auditor negotiate with a client about misstatements? What are some factors that would enter the negotiation process?

\section{OPTIONAL HANDS-ON INTERNET EXPERIENCE}

Instructors can also give students some hands-on Internet experience on outcome information relating to the case. For example, in 1995 California Micro Devices sued Chan Desaigoudar, its former CEO, for fraud. What was the outcome of that lawsuit? In addition, in 1995, there was a class action lawsuit filed against the company. What was the outcome of that litigation? Finally, what was the outcome of the lawsuit against Coopers and Lybrand? A positive learning experience for students would be to first ask students how a company should report litigation on its financial statements. Then give the students some hands-on Internet experience by having them accessing publicly available information (10Qs and 8-Ks) on the Internet (http://accounting.rutgers.edu and select Edgar) to see how California Micro Devices actually disclosed this information.

\section{CLASS DISCUSSION GUIDE}

\section{Question 1 - Auditor's Ethical Responsibilities}

There is no specific ethical ruling concerning how an auditor should react when asked to be an informant or whistle-blower against a client. In the case of the IRS approaches the auditor to be a tax informant, an applicable rule is Rule 301 of the AICPA's Code of Professional Conduct on "Confidential Client Information." Under that rule, the auditor should not divulge confidential information about the chairperson's tax liabilities or else its relationship with the management of the company will be seriously strained. However, if the information is documented in the auditor's audit working papers, then the auditor may have to make the information available to the IRS. This is because information obtained by the auditor from the company is not privileged and hence must be disclosed if the IRS subpoenas the working papers through a court. If the working papers are subpoenaed, the auditor should immediately inform the company. The company's legal counsel may wish to challenge the subpoena.

In the case of the SEC approaches the auditor to be a whistle-blower relating to the chairperson's insidertrading activities, the same confidentiality rule applies. Usually, the auditor does not document information relating to a client's insider-trading activities. Rather, the information is orally communicated to the client's audit committee. Therefore, the SEC is more likely to seek the auditor's verbal testimony. If verbal testimony is requested, then an applicable auditing standard is SAS No. 54, "Illegal Acts by Client." Under this standard, the insider-trading activity will be considered an illegal act that has an indirect-effect on the company's financial statements. In other words, the trading activity will not affect its financial statements unless there is a fine or sanction by the SEC. As an indirecteffect illegal act, the auditor should consider modifying the audit report accordingly. If the audit report were modified to reflect the illegal act, it would have effectively been a form of whistle blowing. As such, the auditor should consult with its legal counsel before making the disclosure decision.

Section 301 of the Sarbanes-Oxley Act of 2002 requires the audit committee to establish procedures for the receipt, retention, and treatment of complaints and anonymous employee tips regarding irregularities in the company's accounting methods, internal controls, or auditing matters. Moreover, Section 403 of the Act establishes disclosure 
requirements for stock transactions by directors and officers who own more than 10 percent of a publicly traded company's stock. Although these two sections of the Act are not directly related to how an auditor should react when asked to be an informant or whistle-blower against a client, they are indirectly related to the auditor's responsibilities as a whistle-blower. First, under Section 301, the auditor has the responsibility to discuss with the audit committee fraud (including insider- trading activities) involving senior management. Effectively, the auditor serves as a whistleblower for the audit committee. Note that the auditor is also required to communicate insider-trading activities to the audit committee in compliance with the auditing standard, SAS No.61, "Communications with Audit Committee."

Second, under Section 404 of the Act, an auditor must express an opinion on the CEO and CFO's report on internal control as part an audit engagement. This includes the auditor's report on material deficiencies in internal control that cause the company fails to disclosure insider-trading activities in compliance with Section 403 of the Act. Again, the audit effectively serves as a whistle-blower on insider-trading activities for the SEC. Note that the auditor also is required to report any insider-trading activity as a reportable condition in compliance with the audit standard, SAS No.60, Reportable Conditions.

\section{Question 2 - Auditor's Legal Responsibilities}

The auditor's legal responsibilities differ under the statutory and the common laws. Under Section 10(b) and Rule 10b-5 of the 1934 Act, the general elements of proof that the company's shareholders must establish to make a prima facie case are: (1) The auditor's audit report contains material misleading statements; (2) The auditor had knowledge of the misleading statements and had committed scienter -- a mental state embracing intent to deceive, manipulate, or defraud; (3) The company's shareholders placed reliance on the misleading statements, and (4) The company's shareholders had sustained actual damages as a result of their reliance on the misleading statements. Given these general elements of proof, there are several defenses available to the auditor: (1) There was no scienter, that is, the auditor had no intention to deceive, manipulate, or defraud the company's shareholders; (2) The shareholders' losses were not due to their reliance on the auditor's statements in the audit report, and (3) The statute of limitations has expired. Since the 1934 Act does not specify the time within which a lawsuit must be brought, the general statute of limitations applies. The 'no scienter' defense is probably the best defense for the auditor under the statutory law. It is also known as a 'good faith' defense in that the auditor must prove that it acted in good faith (i.e., no intention to deceive, manipulate, or defraud) and that it has no knowledge of the misleading misstatements.

In the case of tort action under the common law, the general elements of proof that the company's shareholders must establish to make a prima facie case are: (1) The auditor knew that the audit report would be used by the shareholders for investment decision making; (2) The auditor knew that the company's shareholders would rely on the audit report for investment decision making, and (3) Some action by the auditor that linked the auditor's negligence to the shareholders' financial losses. In other words, a causal connection has to exist between the two parties. There are several defenses available to the auditor: (1) Non-negligent performance in the audit of the company, that is, the audit was conducted in accordance with generally accepted auditing standards; (2) Lack of privity of contract, that is, there was no implied or expressed contract between the auditor and the shareholders of the company, and (3) Absence of a causal connection, that is, the shareholders have not relied on the audit report in their investment decision making. The absence of a causal connection is probably the best defense for the auditor under the common law. For example, the auditor could argue that there were many other sources of investment information that the shareholders have relied upon for investment decision. Therefore, there was only a remote connection between the auditor's report and the shareholders' reliance on the report.

\section{Question 3 - Auditor's Professional Responsibilities}

The Statement of Auditing Standards (SAS) No.84, "Communications between Predecessor and Successor Auditors," requires the successor auditor to communicate with the predecessor auditor. The predecessor auditor should respond fully and promptly to the successor auditor's inquiry. In addition, under the confidentiality rule in the Code of Professional Conduct, the predecessor auditor should request the company's permission to respond to the successor auditor's inquiry and to release the working papers. 
In 1989, when the predecessor auditor leaves amid concerns of improper revenue cut-off procedures and incompetent financial personnel at the company, the successor auditor should contact the predecessor auditor for information. The successor auditor should make inquiries regarding the disagreements with the company's management on accounting and auditing procedures, especially the improper revenue cut-off procedures and incompetent financial personnel. Moreover, the successor auditor should ask the predecessor auditor about integrity of the company's management. The successor auditor should also determine from the predecessor auditor the reasons for the change of auditors. Finally, the successor auditor might request the predecessor's working papers on the company. The form of communication with the predecessor auditor could be oral or written.

In 1995, the predecessor auditor withdraws its audit report associated with the 1994 financial statements that the successor auditor believes should be revised. Since the predecessor auditor withdrew its audit report associated with the previous years' financial statements, this constitutes an unusual circumstance. Under SAS No.84, the successor auditor should arrange a special meeting with the management of the company and the predecessor auditor to discuss about circumstances surrounding the withdrawal of the audit report.

\section{REFERENCES}

1. American Institute of Certified Public Accountants (AICPA). 1988. Illegal Acts by Clients. Statement on Auditing Standards No. 54. New York, NY: AICPA.

2. American Institute of Certified Public Accountants (AICPA). 1988. Confidential Client Information. AICPA Code of Professional Conduct Rule 301. New York, NY: AICPA.

3. American Institute of Certified Public Accountants (AICPA). 1988. Reportable Conditions. Statement on Auditing Standards No. 60. New York, NY: AICPA.

4. American Institute of Certified Public Accountants (AICPA). 1997.Communications Between Predecessor and Successor Auditors. Statement on Auditing Standards No. 84. New York, NY: AICPA.

5. Securities and Exchanges Commission (SEC). Rule 10(b) and Rule 10b-5 of the Securities and Exchanges Act of 1934 .

6. Securities and Exchanges Commission (SEC). Sarbanes-Oxley Act of 2002.

\section{NOTES}




\section{NOTES}

